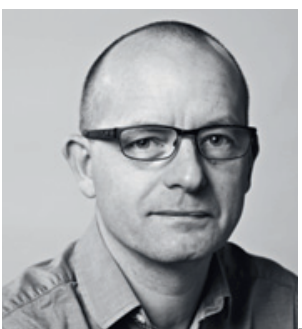

Are Brean (f. 1965) er ph.d., seniorredaktø

i Tidsskrift for Den norske legeforening, overlege ved Nevrologisk avdeling. Oslo universitetssykehus, og leder i Norsk nevrologisk forening. Forfatter har fylt ut ICMJE-skjemaet og oppgir ingen interessekonflikter.

\section{Spør først, forsk siden}

«Spør først, grav siden,» oppfordret det gamle Televerket. Det var på den tiden da telefonkatalogen faktisk var en katalog og ikke et nettsted og alle telesignaler gikk gjennom kabler. En overrevet kabel ga merarbeid for Televerket og dager til uker uten telefonkontakt med omverdenen for de berørte abonnentene - problemer som kunne vært unngått med et enkelt spørsmål på forhånd.

Forskningsfrihet er en frihet til å grave etter ny kunnskap. Denne friheten er grunnleggende for god forskning. Likevel har samfunnet plikt til å regulere måten det graves etter kunnskap på. Det er det mange gode grunner til, slik det har vært omtalt i Tidsskriftet en rekke ganger (1-3). Derfor er medisinsk forskning strengt regulert $\mathrm{i}$ både internasjonale overenskomster og i nasjonale lover og forskrifter. Slike reguleringer skaper også forutsigbarhet for den enkelte forsker fordi de verner mot tilfeldige avgjørelser.

I Norge ble mye av regelverket på dette området samlet i helseforskningsloven i 2008 (4). Loven i seg selv er naturlig nok lite egnet som praktisk rettesnor for forskere, men den har ført til forenkling av søknadsprosedyrene. Det er nå mer oversiktlig hvem man bør spørre før prosjektet igangsettes. Som hovedregel skal alle medisinske og helsefaglige forskningsprosjekter forhåndsgodkjennes av en av de regionale komiteene for forskningsetikk (REK) (5). All forskning som involverer mennesker krever også informert, dokumenterbart samtykke fra de involverte (5). I tillegg må man stille seg selv noen enkle kontrollspørsmål før datainnsamlingen starter:

- Er dette en prospektiv klinisk studie? I så fall må den sannsynligvis registreres i en av de internasjonale studiedatabasene (1). Blant annet for å hindre selektiv publisering er det et krav at registreringen skjer før første pasient inkluderes.

- Inkluderer studien innsamling, registrering og/eller lagring av personopplysninger? I så fall må den meldes til et personvernombud (6). Dette gjelder uavhengig av om studien defineres som kvalitetssikring eller som forskning.

- Er utprøvning av legemidler eller medisinsk utstyr en del av studien? I så fall må det også søkes henholdsvis Statens legemiddelverk eller Helsedirektoratet (7).

Den enkleste måten å sikre at alt dette er ivaretatt på, er å utarbeide en forskningsprotokoll. I tillegg til å virke avklarende for forskeren selv, er en systematisk protokoll nyttig i alle faser - når tillatelser og finansiell støtte skal søkes, når prosjektet skal legitimeres på eget sykehus eller i egen organisasjon og når resultatene skal publiseres. Også i rene kvalitetssikringsprosjekter kan en slik protokoll være svært nyttig. Det finnes mange gode maler for forskningsprotokoller. En artikkel i Tidsskriftet fra 2002 gir nyttige råd i utformingen (8). Men selv når alle de nødvendige tillatelser er innhentet på forhånd og prosjektet er vitenskapelig interessant, kan man få problemer med å få studien publisert. Alle medisinske tidsskrifter har nemlig en selvstendig plikt til etisk vurdering av prosjektet som er utført. Denne plikten er nedfelt i blant annet Helsinki-deklarasjonen (9) og i tidsskriftenes forpliktende samarbeid i International Committee of Medical Journal Editors (ICMJE) (10) og Committee on Publication Ethics (COPE) (11). Grunnen til dette er åpenbar: De statlige organene, som de regionale etiske komiteer og personvernombudene, forhåndsgodkjenner planer, mens tidsskriftene i ettertid vurderer hva som faktisk er gjort. Disse rollene er komplementære. For å forbli i tittelens allegori: Selv om du har fått gravetillatelse på forhånd, er det tidsskriftenes oppgave å påse at du ikke har gravd over noen kabler underveis. Et eksempel på dette er kvalitetssikringsprosjekter, som etter lovverket kan igangsettes uten godkjenning av den regionale etiske komité og uten samtykke fra pasientene (4). Når det kommer til publisering, er imidlertid skillet mellom kvalitetssikring og forskning mindre interessant (2) - fordi tidsskriftene alltid må vurdere hvorvidt det som faktisk er utført, holder allment aksepterte etiske standarder for publisering, uavhengig av hva prosjektet er forhåndsdefinert som. Tidsskriftene er også forpliktet til å gjøre publiseringsetiske vurderinger som ikke omfattes av de nasjonale lovverkene. Dersom det er mulighet for at enkeltpasienter kan bli gjenkjent, må de gi samtykke til publisering. Dette praktiseres som regel strengt. I Tidsskriftet krever vi at vårt standard samtykkeskjema benyttes (12).

Gode forskningsprosjekter er ikke nødvendigvis store eller kompliserte. Med enkle metoder kan det ofte graves frem viktig ny kunnskap. Allikevel må de nødvendige tillatelser alltid innhentes før prosjektet igangsettes. Noe av det verste vi i Tidsskriftet vet, er å måtte refusere interessante manuskripter fordi dette ikke er i orden. Spør før du forsker. Etterpå kan det være for sent.

\section{Litteratur}

. Bretthauer M, Haug C. Uten registrering, ingen publisering! Tidsskr Nor Legeforen 2009: 129: 733 .

2. Haug C. Bare spør! Tidsskr Nor Lægeforen 2010; 130: 1445

3. Simonsen S, Nylenna M. Regulering av medisinsk forskning-hvorfor og hvordan. Tidsskr Nor Lægeforen 2004; 124: 2133-6.

4. LOV 2008-06-20 nr. 44: Lov om medisinsk og helsefaglig forskning (helseforskningsloven). www.lovdata.no/all/hl-20080620-044.html (22.5.2012)

5. Regionale komiteer for medisinsk og helsefaglig forskningsetikk. http://helseforskning.etikkom.no/ikbViewer/page/forside?lan=2 (22.5.2012)

6. Personvernombudet for forskning. www.nsd.uib.no/personvern/ (22.5.2012).

7. Veileder til lov 20. juni $2008 \mathrm{nr}$. $44 \mathrm{om}$ medisinsk og helsefaglig forskning thelseforskningsloven). www.regjeringen.no/nb/dep/hod/dok/veiledninger og brosjyrer/ 2010/Neileder-til-lov-20-juni-2008-nr-44-om-medisinsk-og-helsefaglig-forskninghelseforskningsloven.html?id=599512 (22.5.2012).

8. Bakketeig LS, Magnus P. Hva er en forskningsprotokoll og hvorfor er den nødvendig? Tidsskr Nor Lægeforen 2002; 122: 2464-7.

9. Declaration of Helsinki. Ethical principles for medical research involving human subjects. World Medical Association, 2008. www.wma.net/en/30publications/ 10 policies/b3/index.html (22.5.2012)

10. International Committee of Medical Journal Editors. www.icmje.org/ (22.5.2012).

11. Committee on Publication Ethics. www.publicationethics.org/ (22.5.2012).

12. Haug C. Ser du hvem jeg er? Tidsskr Nor Legeforen 2008; 128: 1935 